\title{
Examining Mathematical Problem-Solving Beliefs among Rwandan Secondary School Teachers
}

\author{
Aline Dorimana \\ African Centre of Excellence for Innovative Teaching and Learning Mathematics and \\ Science (ACEITLMS), University of Rwanda College of Education (URCE), Rwanda \\ https://orcid.org/0000-0002-7060-207X \\ Alphonse Uworwabayeho \\ School of Education, University of Rwanda College of Education (URCE), Rwanda \\ https://orcid.org/0000-0003-2651-1848 \\ Gabriel Nizeyimana \\ School of Education, University of Rwanda College of Education (URCE), Rwanda \\ https://orcid.org/0000-0002-6559-1249
}

\begin{abstract}
This study explored teachers' beliefs about mathematical problem-solving. It involved 36 identified teachers of Kayonza District in Rwanda via an explanatory mixed-method approach. The findings indicate that most teachers show a positive attitude towards advancing problem-solving in the mathematics classroom. However, they expose different views on its implementation. Role of problem-solving, Mathematical problems, and Problem-solving in Mathematics were identified as main themes. Problem-solving was highlighted as an approach that helps teachers use time adequately and helps students develop critical thinking and reasoning that enable them to face challenges in real life. The study recommends teacher professional development initiatives with their capacity to bring problem-solving to standard.
\end{abstract}

Keywords: competence-based curriculum; mathematical problemsolving; teachers' beliefs; secondary school; Rwanda

\section{Introduction}

Developing countries, including Rwanda, have been extremely devoted to achieving the international commitments to Education for All (EFA) and the 2030 Millennium Developments Goals (MDGs). In this context, the education sector was commissioned to ensure quality education in all subjects. As stipulated in the competence-based curriculum (CBC), the purpose of education is to develop the most critical skills of learners not only to meet the employment demands but to 
succeed in the 21 ${ }^{\text {st }}$ century. Problem-solving is one of them (Rwanda Basic Education Board [REB], 2015). Within problem-solving, students are supported to explore tasks in multiple justifiable and innovative ways and to construct logical reasoning in finding solutions (Barak, 2013). Yet, the realization of this outcome will depend on teachers' abilities to provide appropriate opportunities for students to grow such skills (Xenofontos \& Andrews, 2012).

Traditional teacher practices were reported to be the most limiting factor for students to apply mathematics knowledge (Nsengimana et al., 2020; Ukobizaba et al., 2019). These practices are strongly related to the beliefs teachers hold on a particular subject (Arikan, 2016; Beswick, 2012; Marshman \& Goos, 2018; Polly et al., 2013; Siswono et al., 2019). Teachers' beliefs influence their pedagogical decision-making and the patterns of interaction in mathematics classrooms(Beswick, 2019; Bobis et al., 2015; Zakaria \& Maat, 2012). Thus, it is vitally important to develop a good understanding of teachers' beliefs about mathematical problem-solving to improve their professional development, teacher training programs, and the successful implementation of the CBC.

According to Hwang and Riccomini (2016), problem solving refers to the no immediate activities that students do while modelling situations using mathematics, making reasoned assumptions, and interpreting solutions in a context. Teachers should engage students in meaningful activities that require them to think, reason, create, critique, and innovate (Barak, 2013). These skills definitely improve school performance (Cheng et al., 2018). Palraj, Dewitt and Alias (2017) added that problem-solving skills are what employers look for in their employees.

Several studies were conducted on teachers' beliefs about mathematical problemsolving. These studies share a common view of improving academic performance and the classroom instruction. However, studies that seek to understand teachers' beliefs about problem-solving for successful integration of such skills while teaching remain sparse. In addition, how teachers view problem-solving in mathematics teaching is unknown in Rwanda. To add knowledge to the existing and close the gap in the context of Rwanda, the study sought to explore what inservice mathematics teachers believe about mathematical problem-solving while implementing $\mathrm{CBC}$. The outcome of the study would inform the teacher training programs. The teacher training programs would develop knowledge toward influencing more positive beliefs held by teachers, which will result in changing their practices. It is also hoped that identifying these beliefs would be useful to mathematics teacher educators and school leaders whose ultimate mission is effective curriculum implementation.

\section{Literature review}

Research toward beliefs in mathematics education is vast, and researchers have articulated a myriad of conceptualizations to explain this term. However, investigations of this are beyond this study's scope, but interested readers may look into Pajares (1992) and Roesken, Pepin \& Toerner (2011). In this study, we focus on the literature that covers mathematics teachers' beliefs about mathematical problem-solving. 
The mathematical beliefs, handled in this study as a collection of values judgments of an individual developed or formulated from experiences and gives meaning to an action, have gained an important place in the learning process (Nizeyimana \& Ruksana, 2013; Raymond, 1997). Research reports that teachers' practice is often affected by what they think and know about mathematics' pedagogy (Moh'd et al., 2021; Siswono et al., 2019). The most important thing, such as prior knowledge, past school experience, qualification level, teaching experiences, and classroom situation, strongly influences mathematical teachers' beliefs and teaching practices (Ren \& Smith, 2017; Siswono et al., 2017). These beliefs and practices can then limit what students get from learning. Siswono et al. (2019) highlighted that those teachers who believe mathematics as a collection of rules and formulas are likely to teach procedural knowledge alone than those who believe otherwise. Thus, beliefs should be understood to achieve the learning provisions.

\subsection{Theoretical framework}

The mathematical beliefs that teachers hold are based on how they conceptualize the nature of mathematics, mathematics teaching, and learning (Ernest, 1989). Thus, the way they bring and or develop problem-solving in the classroom is primarily based on these beliefs (Siswono et al., 2017). Ernest (1989) described the mathematical beliefs as the instrumentalist, the Platonist, and the problem-solving views. The instrumentalist believes mathematics is a useful subject that collects unchangeable rules and unrelated facts to solve problems. The Platonist views mathematics as an integrated science where structures and truths are connected through logic and reasoning for individuals. The problem-solving view of mathematics is a powerful subject that opens the space for making continuous discoveries that are transformed into knowledge. The interconnection of these views with the nature of mathematics, teaching, and learning can be seen from the work of Beswick (2012).

The Rwandan CBC is structured in a way that encourages students to take an active role in their learning process with the help of teachers and peers. The learning process mainly requires prior knowledge and guidance from teachers. Thus, the particular study follows the cognitive learning theory (Fox, 1997; Nabavi, 2012). This study will also examine the relationship between teacher beliefs and how they structure the problem-solving model to help learners interact with the problem. A large number of scholars (Arikan, 2016; Beswick, 2012; Memnun et al., 2012; Marshman \& Goos, 2018; Niyukuri et al., 2020; Polly et al., 2013; Siswono et al., 2019) investigated beliefs of teachers and teaching practices regarding the nature of mathematics, teaching, and learning. To our knowledge, little attention was given to in-service secondary mathematics teachers' beliefs dealing with problem-solving. In this spirit, the present article adds knowledge to the existing by reporting the study results that investigated the beliefs of inservice secondary mathematics teachers about mathematical problem-solving.

\subsection{The context of the study}

The current study was part of a large project investigating how grade 11 students (age between 16 and 19) can enhance their ability to solve mathematics problems using a problem-based learning model. The main idea in the project's initial phase 
was to have general baseline information of the teachers' knowledge on the advancement of problem-solving emphasized in the CBC. Thus, we decided to explore teachers' beliefs about mathematical problem solving and the teaching practices they associate to these beliefs within CBC. These teachers' beliefs could promote or hinder students' mathematical problem-solving abilities. The project aimed to design an intervention model based on these findings. The goal was to explore whether teachers' beliefs about mathematical problem solving and teaching practices could be shaped as a result of participating in the intervention focusing on promoting students' abilities in solving mathematical problems.

\section{Methodology}

Since the purpose of the study was to explore teachers' beliefs about mathematical problem-solving while implementing CBC in Rwanda, the explanatory-mixed methods research design was considered appropriate (Cresswell, 2014). In this design, quantitative data were collected and analyzed in the first phase of data collection. Then based on the results of quantitative data, a tool was designed to collect qualitative data in the second phase of data collection. This approach is suited to research exploring and qualitatively understanding how individuals' actions are developed and or shaped by their experience. Quantitative data were obtained through questionnaires, while qualitative data were gathered from interviews.

\subsection{Research participants}

The participants of the study were 36 identified mathematics teachers ( 7 females and 29 males). They come from 15 secondary schools of Kayonza District in Rwanda. The predominant age range of the participants was 30-39 years (24 teachers). The predominant teaching experience of the participants was 6-10 years (19). The median experience in years for the respondents was six years in teaching.

Table 1. Teacher's characteristics. Note: the number in parenthesis is the sample teachers (n), Each column should be read independently, N/A is missing data

\begin{tabular}{|c|c|c|c|c|c|}
\hline Gender & $\begin{array}{l}\text { Age } \\
\text { range }\end{array}$ & Experience & Qualification & $\begin{array}{l}\text { Teaching } \\
\text { grade }\end{array}$ & $\begin{array}{l}\text { Teaching } \\
\text { combination }\end{array}$ \\
\hline $\begin{array}{l}\text { Male } \\
(29)\end{array}$ & $\begin{array}{l}\text { Under } \\
25(1)\end{array}$ & $\begin{array}{l}\text { Below } 2 \\
\text { years (2) }\end{array}$ & A2 (1) & $\begin{array}{l}\text { Ordinary } \\
\text { level (12) }\end{array}$ & $\begin{array}{c}\text { General } \\
\text { mathematics (10) }\end{array}$ \\
\hline $\begin{array}{l}\text { Female } \\
(7)\end{array}$ & $\begin{array}{c}25-29 \\
(7)\end{array}$ & $\begin{array}{l}2 \text { to } 5 \text { years } \\
(10)\end{array}$ & A1 (9) & $\begin{array}{l}\text { Advanced } \\
\text { level (7) }\end{array}$ & $\begin{array}{c}\text { Subsidiary } \\
\text { mathematics (3) }\end{array}$ \\
\hline & $\begin{array}{c}30-39 \\
(24)\end{array}$ & $\begin{array}{c}6 \text { to } 10 \\
\text { years }(19)\end{array}$ & A0 (24) & $\begin{array}{l}\text { Both } O \text { and } \\
\text { A level (16) }\end{array}$ & $\begin{array}{c}\text { Core } \\
\text { mathematics (15) }\end{array}$ \\
\hline & $\begin{array}{c}40-49 \\
(1)\end{array}$ & $\begin{array}{l}11 \text { to } 15 \\
\text { years }(1)\end{array}$ & $\mathrm{N} / \mathrm{A}(2)$ & N/A (1) & $\begin{array}{l}\text { Both core and } \\
\text { subsidiary (5) }\end{array}$ \\
\hline & $\begin{array}{c}50-59 \\
(1)\end{array}$ & $\begin{array}{l}\text { Above } 15 \\
\text { years (3) }\end{array}$ & & & $\mathrm{N} / \mathrm{A}(3)$ \\
\hline & $\begin{array}{c}\text { Above } \\
60(1)\end{array}$ & N/A (1) & & & \\
\hline & $\begin{array}{c}\text { N/A } \\
(1)\end{array}$ & & & & \\
\hline
\end{tabular}

Three teachers were in their first year of teaching mathematics, while the longestserving teacher was in his 33rd year. Most teachers (24) have bachelor's degrees 
(A0), with a few teachers (9) have a university diploma (A1), and only one teacher has advanced level certificates (A2). Out of 36 teachers, 27 were qualified to teach mathematics at secondary levels, from which 17 indicated that they had attended some professional training on the reformed curriculum in Rwanda, the CBC.

\subsection{Data collection tools, procedures, and analyses}

The study used the mathematical problem-solving beliefs scale to obtain quantitative data and a semi-structured interview for qualitative data.

\subsubsection{Phase 1: Mathematical problem-solving beliefs scale (MPSBS)}

A questionnaire was used as a research instrument to collect quantitative data in this study. This questionnaire was adapted from four previously developed instruments by Emenaker (1996), Hart (2002), Kloosterman and Stage (1992), Zollman and Mason (1992) to collect data after some modifications and additions. The questionnaire had 23 items and was completed on a five-point Likert scale ranging from strongly disagree (1) to strongly agree (5).

Before using the instrument in the actual data collection, items in the questionnaires were modified to fit the context as evidence of the validity after conducting a pilot study. The internal consistency was also checked to a group of mathematics teachers $(n=33)$ with a reliability coefficient (Cronbach Alpha $=0.659)$ which was considered acceptable. Upon completion, the instrument required participants to complete a demographic/ prior knowledge information including type and name of the school, gender, age, teaching experience, highest qualification, classes and combinations that the teacher teaches, and if $\mathrm{s} /$ he has attended professional development programs aiming at promoting problemsolving in the mathematics teaching process and one question regarding knowledge about problem-solving.

The questionnaires were distributed paper/ pencil by researchers to teachers in their respective schools. The questionnaire took approximately 20 minutes to be completed. MS Excel 2016 was used to calculate means and standard deviations. The Mean was computed by averaging the chosen category along with all 36 teachers on every MPSBA item. Each category was assigned a specific score (4: strongly agree, 3: agree, 2: disagree, and 1: strongly disagree). Frequency tables and percentages were used to analyze data collected for the first stage. Scales 1 and 2 were gathered to the disagreement stream to analyze the data, while scales 4 and 5 were gathered to the agreement stream. The neutral scale was omitted and put aside as not applicable (NA). All the questionnaire items in Table 2 were intended to gain insights from teachers about the itemized beliefs. A description to get respondents' overall view concerning each statement to see on response to questions were included in the analysis.

\subsubsection{Phase 2: A semi-structured interview (SSI)}

A series of in-depth interview questions were developed with the aim to explore the problem-solving beliefs of teachers. Interview questions were structured based on the results of the questionnaire of the mathematical problem-solving beliefs used in the first stage of data collection. The most merging themes revolved around the meaning of problem-solving in mathematics. The interview guide consisted of six questions: two questions regarding the understanding of 
problem-solving in mathematics, three questions regarding understanding mathematical problems, and one question regarding teaching practices employed to bring problem-solving in teaching. The interview questions were as follows:

What is your opinion on problem-solving? Is problem-solving more important; why? What do you think about understanding the mathematical problem? Is it necessary to take a long time to solve the mathematical problems; Why? Is the result for the solution to a problem more important than how it is solved? In what way do you think or do you bring problem-solving in actual mathematics?

Based on the questionnaire results, the beliefs of teachers were classified into instrumentalist, Platonist, and problem-solving views. In each class, one teacher was selected purposively to participate in the interview. The reason for this selection was to include teachers of grade 11 students that the large project focuses on. These interviews were planned to provide an in-depth description of teacher's beliefs about mathematical problem-solving. Interviews were performed and recorded on tape and lasted approximately seven to ten minutes. The data from interviews were analyzed using a thematic approach (Orodho et al., 2016). Data are reduced and displayed in this analysis, and then conclusions and verifications are drawn (Miles \& Huberman 1994). Finally, in this analysis, conclusions were sought to determine the beliefs of teachers and their knowledge regarding problem-solving in mathematics.

\subsection{Ethical consideration prior to data collection}

The study followed ethical approval from the research and innovation unit at the University of Rwanda College of Education (URCE). This ensured that the researcher has all the documents that the school administration may ask for and teachers' cooperation in conducting the current research. All participants provided consent forms to ensure voluntary participation and were communicated that they were allowed to withdraw from the study at any stage. The researcher collected data from mid-January to mid-February of the academic year 2019.

\section{Findings}

In terms of what secondary mathematics teachers understand about problemsolving, participants were probed to affirm their understanding of problemsolving as applied in mathematics (see Table 2 and Figure 1). Most items were scored above the average (mean scores of 2.5), except item 14 [It does not matter whether students cannot get the right...] that had 2.448 out of 4 scores (See Table 2). 
Table 2. Mean scores and standard deviation (SD) of Teachers' beliefs about problemsolving

\begin{tabular}{|c|c|c|c|}
\hline $\begin{array}{l}\mathrm{N} \\
\mathrm{O}\end{array}$ & Problem-Solving Statements & Mean & SD \\
\hline 1 & Problem-solving should be part of the mathematics curriculum & 2.516 & 1.092 \\
\hline 2 & The understanding of a given problem is essential to solve it & 3.788 & 0.415 \\
\hline 3 & Dealing with problems provides new ways to find solutions & 3.625 & 0.492 \\
\hline 4 & $\begin{array}{l}\text { Examples given in-class activities should develop problem- } \\
\text { solving skill }\end{array}$ & 3.722 & 0.454 \\
\hline 5 & Skill in computation should precede word problems & 3.323 & 0.871 \\
\hline 6 & Knowledge constructed during solving problems is deeper & 3.552 & 0.506 \\
\hline 7 & $\begin{array}{l}\text { A good explanation of reasoning is regarded more than correct } \\
\text { answers }\end{array}$ & 3.100 & 1.062 \\
\hline 8 & $\begin{array}{l}\text { Problem-based learning results in higher levels of } \\
\text { understanding than traditional teacher-centered instruction }\end{array}$ & 3.444 & 0.577 \\
\hline 9 & $\begin{array}{l}\text { Children enter nursery school with considerable mathematical } \\
\text { experience, a partial understanding of many mathematical } \\
\text { concepts, and some important mathematical skills }\end{array}$ & 2.938 & 0.982 \\
\hline 10 & Students are able to construct their own mathematics problems & 2.786 & 0.995 \\
\hline 11 & $\begin{array}{l}\text { It is often easy to interpret students' wrong answer when I am } \\
\text { teaching mathematics }\end{array}$ & 3.034 & 0.944 \\
\hline 12 & $\begin{array}{l}\text { All of my students would be good in mathematics if they work } \\
\text { hard at it }\end{array}$ & 3.548 & 0.624 \\
\hline 13 & $\begin{array}{l}\text { Students strive for getting correct answers rather than } \\
\text { understanding mathematical concepts }\end{array}$ & 2.967 & 0.850 \\
\hline 14 & $\begin{array}{l}\text { It does not matter whether students cannot get the right answer } \\
\text { as long as they understand the mathematical concepts inherent } \\
\text { to the problem }\end{array}$ & 2.448 & 0.985 \\
\hline 15 & $\begin{array}{l}\text { When students are familiar with problem-solving, they are no } \\
\text { longer afraid of questions about word problems }\end{array}$ & 3.679 & 0.548 \\
\hline 16 & Mathematics is very important in daily life & 3.743 & 0.611 \\
\hline 17 & $\begin{array}{l}\text { In daily life, mathematics matters not only for making } \\
\text { calculations }\end{array}$ & 3.161 & 0.969 \\
\hline 18 & $\begin{array}{l}\text { A major goal of mathematics instruction is to help children } \\
\text { develop the belief that they have the power to control their own } \\
\text { success in mathematics }\end{array}$ & 3.441 & 0.786 \\
\hline 19 & $\begin{array}{l}\text { Knowledge of mathematics concepts is important in the } \\
\text { development of problem-solving skill }\end{array}$ & 3.806 & 0.401 \\
\hline 20 & $\begin{array}{l}\begin{array}{l}\text { Mathematical problem-solving skill is gained through } \\
\text { practicing }\end{array} \\
\end{array}$ & 3.657 & 0.539 \\
\hline 21 & $\begin{array}{l}\text { I would provide routine problems before introducing new } \\
\text { concepts in mathematics }\end{array}$ & 3.233 & 0.971 \\
\hline 22 & $\begin{array}{l}\text { A successful problem solver is one who is able to solve } \\
\text { situations that call for mathematical concepts }\end{array}$ & 3.300 & 0.750 \\
\hline \multirow[t]{2}{*}{23} & $\begin{array}{l}\text { Repeated practices and reinforcement of the mathematical } \\
\text { content is an appropriate process for learning }\end{array}$ & 3.429 & 0.790 \\
\hline & Overall & 3.315 & 0.748 \\
\hline
\end{tabular}


The item-14 shows that many teachers rated it in the disagreement direction. Thus, few teachers agreed on it. The item that got the highest scores is 19 [Knowledge of mathematics concepts is important ...]. It got 3.806 mean scores. It shows that many teachers rated it in the agreement direction. There was a controversy in rating items- 1 and -7 as they display a large standard deviation (SD of 1.092 and SD of 1.062, respectively). Thus, some teachers agreed while others disagreed with them (see Table 2).

While Table 2 displays scores on each item, the stacked column Figure 1 displays the frequency of teachers that agreed or disagreed on each item. Most of the teachers tend to have a positive attitude towards statements advancing problemsolving in the mathematics classroom. For instance, they all (100\%) confirmed that examples given in-class activities should develop problem-solving skills [item-4], and knowledge of mathematics concepts is essential in the development of problem-solving skills [item-19] (see Figure 1).

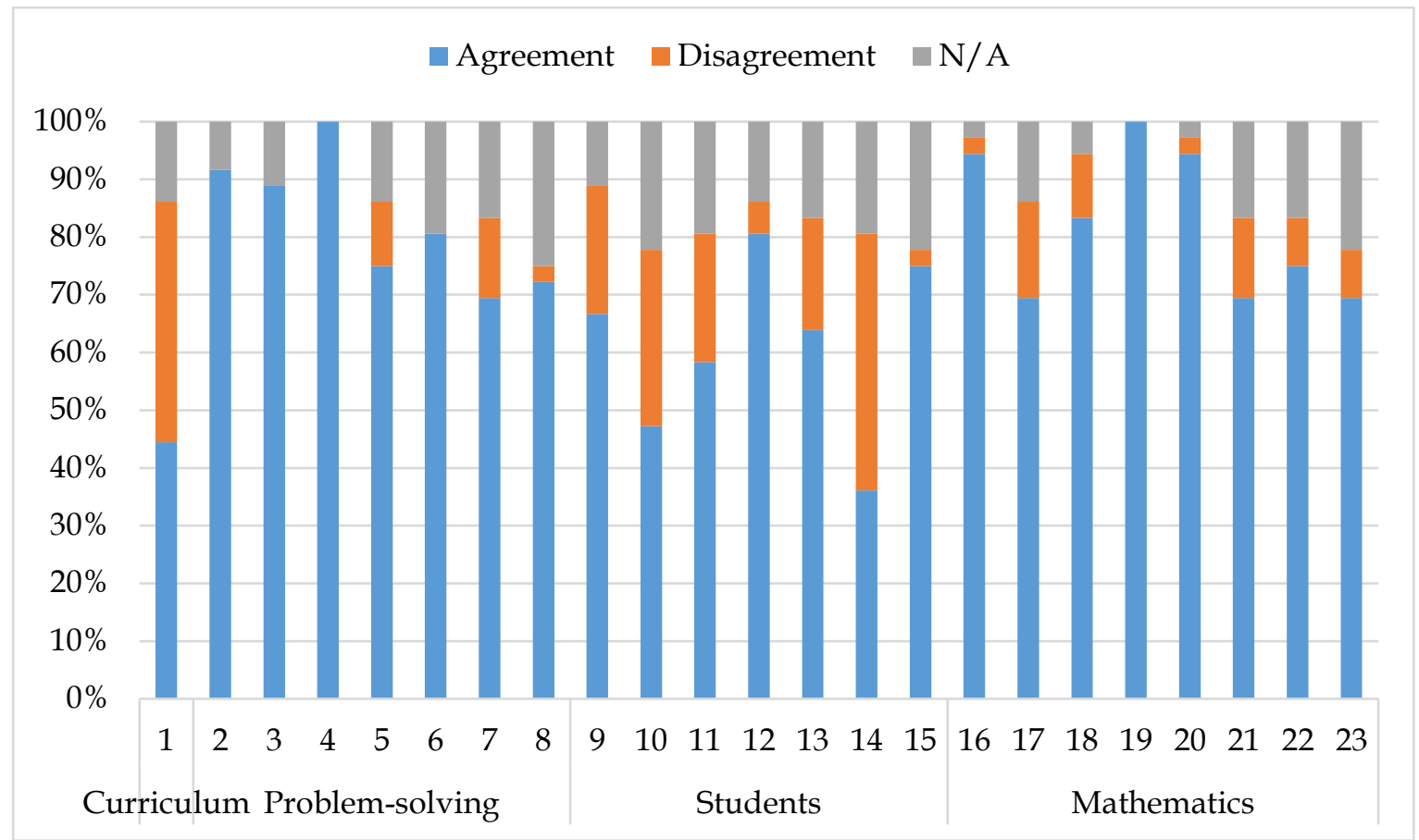

Figure 1: Mathematics Problem-Solving Beliefs Scale items. Note: the percentage on the vertical axis is the number of teachers, while the numbers on the horizontal axis are the MPSBS items.

However, few teachers agreed $(44 \%)$ that problem solving should be part of the mathematics curriculum [item-1], believe (47\%) that students can construct their mathematics problems [item-10], and trust (36\%) that it does not matter whether students cannot get the right answer as long as they understand the mathematical concepts inherent to the problem [item-14]. Most teachers believe that (94\%) mathematics is vital in everyday life [item-16], that (94\%) Mathematical problemsolving skill is gained through practicing [item-20], that $(92 \%)$ one needs to understand a problem in order to solve it [item-2], and that $(89 \%)$ dealing with problems provides new ways to find solutions [item-3]. 
The findings indicate that although many participants show consistent beliefs with the current teaching and learning of mathematics, a deep analysis of some teachers' detailed views was needed to triangulate the data. Three teachers at one school were focused on the deep interview to supplement quantitative data in the questionnaire. In analyzing their views, we found that information raised in the questionnaire matches their views during the interview; however, this made us well capture their beliefs and understand their stands. We made three themes; Role of problem-solving, Mathematical problem, and Problem-solving in Mathematics (see Figure 2).

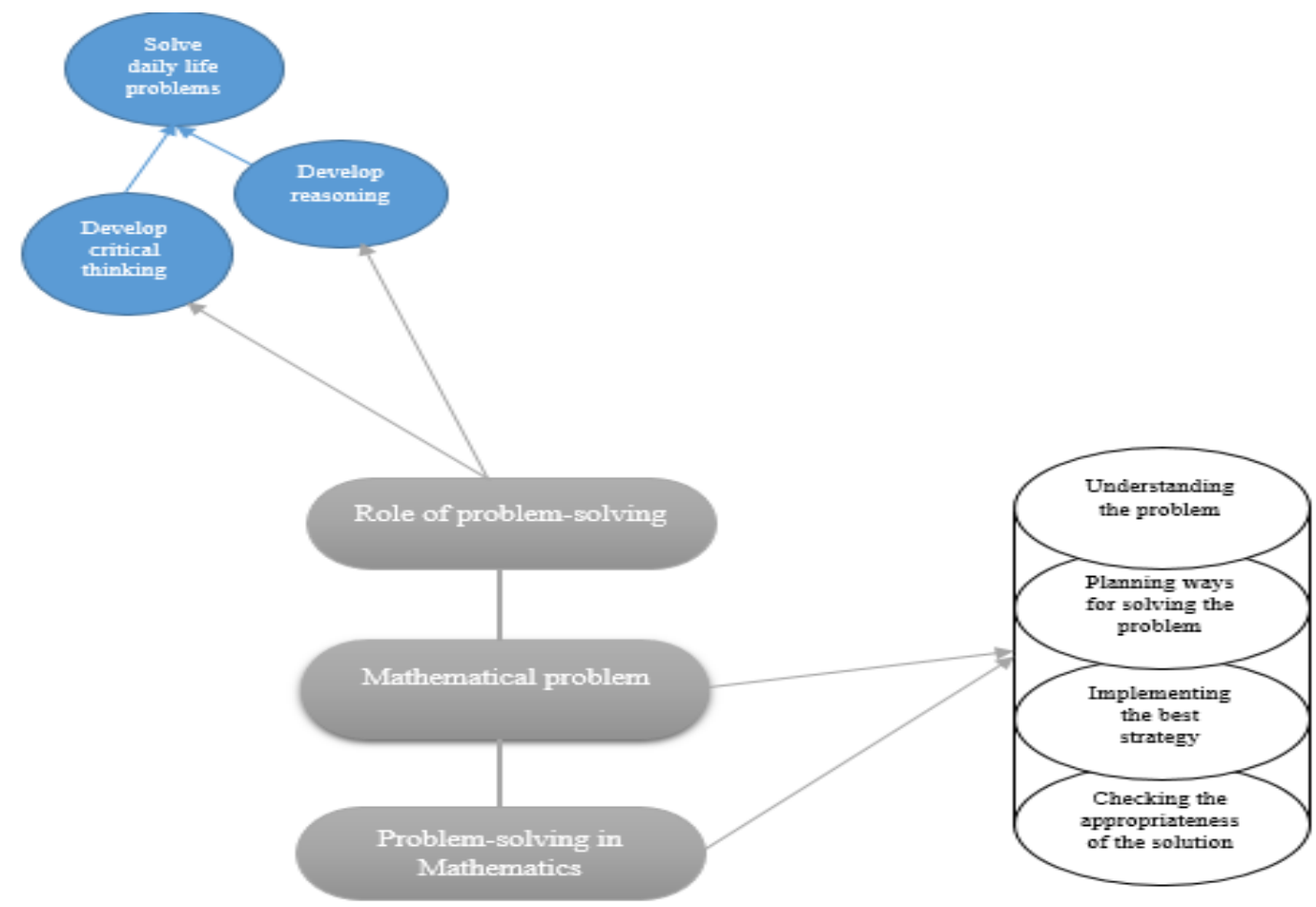

Figure 2: Thematic analysis of problem-solving outputs and their stages

\subsection{Role of problem-solving}

All three teachers are aware of problem-solving, its usability in Mathematics, and its role in daily life. Teachers believe that problem solving is characterized by the "challenge." Teacher-1 said, "Problem-solving is about finding solutions to the problems, and that problem should be challenging with no immediate solution." Similarly, Teacher-2 supplemented that; "When there is a set of problems that one is trying to solve, then he/ she is applying mathematical problem solving, and this problem is tricky and challenging."

Teachers associate problem solving with developing critical thinking and reasoning that help learners face problems in the real world. Teacher-2 ascertained, "When students ask the benefits in real life of studying certain topics, I tell them that problem solving opens their mind in any situation they meet in real life. It opens the minds of students it trains them to think more critically. Also, it helps learners to reason than they do when you give them exercises (repeating 
the learned concepts)." Teacher-3 said, "problem-solving is important because when students are familiar with it, then they are not afraid to face a difficult problem in their lives."

Teachers also believe that problem solving may help them to complete the program on time. Teacher-2 said, "Sometimes when you give a challenging question to students, you may cover a wide content that you cannot cover when you did not provide students with that problem-solving investigation."

\subsection{Mathematical problem}

When asked teachers the importance of understanding the problem, all of them value it. Teacher-1 said, "It is very important to understand a problem because one needs to identify what is given, what is asked, and find ways or strategy to solve the problem." Teacher-2 said, "Understanding the problem is very important because you need to identify the known and unknown in order to solve the problems." Teacher-3 said, "To understand the mathematical problem is to know the formula you should apply to solve a given problem in mathematics."

There was no indication that solving problems also needs a process of looking back, as suggested by scholars. Checking the solution was not mentioned. Teacher-3 focuses only on the calculation-based world problem. Such a teacher needs to understand it in a broader sense to develop students who can use their critical thinking and reasoning to solve the real problems encountered in daily life different from what they solve in Mathematics.

About the needed time to solve a mathematical problem, teachers' views vary. Teacher- 1 suggests that problem-solving needs more time because the more you spend time trying to solve the problem, the more you become very successful in finding the solution with accuracy. Teacher- 2 ascertains that it always depends on the level of difficulty of the problem. "A problem to you might not be a problem to me. So, if it is easy for me, then I solve it in a short time," said Teacher-2. "Not necessary when you understand the problem. You use a long time to solve the problem when you are motivated to do so. When there is no motivation to solve problems that require a long time, you give up," said Teacher-3.

Whether the solution to a problem is more important than how it is solved, both teachers believe that the problem is unnecessary when solving the problem is false or if the strategy does not make sense. They said that one needs to check the strategy; when the strategy is good, then the solution should be correct. They emphasized that the way the problem is solved is very important than the answer.

\subsection{Problem-solving in Mathematics}

When asked teachers how they implement problem-solving in the actual mathematics lesson, they have various considerations. In the case of Teacher- 1 , he first gives a problem to the students; he asks them what is given and any relevant or irrelevant information (generally, students make a list of what is given and what is missing). Then he asks them to think about how they should find the answer to the problem, and finally, he asks them to check if the answer they get really makes sense (to check back if the solution makes sense). For the case of Teacher-2, he poses a question, gives time to students to think about the question, and allows them to solve the problem in various ways. In the case of Teacher-3, 
he poses a similar question to what students are familiar with (procedures) with some tricks; he lets students solve the problem independently with no assistance from his side.

\section{Discussion}

Teachers demonstrate an understanding of the meaning of problem-solving and how they should bring it into their actual teaching of mathematics. It was shown that factors including but not limited to time used to prepare problems, the pressure of finishing the program, the colossal content to cover, and their use of problem-solving approaches influences teacher preparation at the university. About teachers' acceptance of problem-solving, teachers agree with CBC's intentions. They present a good understanding of the meaning of problem-solving and its implementation in the actual teaching practice. The teaching style preferred is different from traditional, were trying to find an appropriate task for problem-solving is encouraged.

Since mathematics is not an abstract concept disconnected from daily life, it should include its applications in other areas. Teachers support learnercenteredness in a way that they believe problem-based learning results in higher levels of understanding than traditional teacher-centered instruction [item-8]; that is why a competence-based curriculum should imbed the problem-solving approaches. Likewise, other studies in Rwanda demonstrated that mathematics teachers need to encourage students to like mathematics by providing interesting teaching methods and real-life examples (Ukobizaba et al., 2019, 2020). Our findings showed that problem-solving is important in such a way that it accelerates critical thinking and reasoning in learners. Mukuka et al. (2020) prevailed on the role of reasoning in mathematics. Reasoning helps one to face challenges encounter in any life situation. Thus, problem-solving does not stop in the classroom; rather, its final stage and role lie in real life after school. This role should inform teachers how they should care about this approach during their planning (Ndihokubwayo et al., 2020) and teaching interaction.

Although most items in a questionnaire displayed a common understanding of the need for problem-solving in mathematics, teachers demonstrated various ways of implementing it during a deep interview with some of them. These ways of implementing problem solving correspond to their beliefs category, i.e instrumental, platonist and problem solving as described by Ernest (1989). This finding is inline with the study of Siswono et al. (2017) who found consistency in teachers related mathematics beliefs and knowledge and pedagogy of problem solving. For instance, Teacher-3, instrumentalists, displayed quite different procedures from his counterparts on implementing problem-solving in mathematics. It is fine to challenge students, but giving similar questions may also limit students develop higher-order thinking skills as it only promotes recalling (Bloom, 1972). Also let students struggle themselves may encourage them to develop problem-solving skills, but if the teacher does not assist, the intention of Rwandan CBC (REB, 2019; Rwanda Basic Education Board, 2015) is lost as it requires guidance from the teacher.

In this study, teachers were not sure of the problem-solving processes that they should emphasize in the classroom. Problem-solving is a mathematical process of 
finding a solution to a problem that requires reasoning and critical thinking skills. It enables individuals to use skills to handle a variety of new situations. To do problem-solving, one needs to (1) Understand the problem (ability to rewrite the problem in another way but still the problem remain the same, to identify what is given, what is asked, what is missing, and or any relevant or irrelevant information), (2) Planning ways to solve the problem (thinking about methodologies to use), (3) Implementing the best strategy (among the strategies that one identified, implement appropriate one), (4) Looking back (checking is the solution is appropriate, make sense to the given problem).

\section{Conclusion and further study orientation}

We have found three key representations of problem-solving in this study. (a) Role of problem-solving. This is characterized by a challenging problem that develops critical thinking and reasoning in students. It then allows them to solve any problem they may face in life out of school. Students being knowledgeable in systematic problem solving may solve time limitations that teachers claim. (b) Mathematical problem. There is a need to understanding the problem; time to solve a problem depends on its nature and level of difficulty, and the utmost importance of process over a final solution. (c) Problem-solving in Mathematics. We have found that problem-solving in mathematics is not systematic across all three teachers due to their belief category, though it has a role in managing teaching time. We intensively assessed teachers' beliefs of mathematics problemsolving in Rwanda. However, there is a need to examine teachers' lesson planning and classroom practices and compare their beliefs displayed in this study.

The current article recommends setting up sustainable long-term programs that support in-service teachers to understand the meaning and implementation of problem-solving in mathematics teaching as required in the competence-based curriculum. Also, to realize the effective teaching modifications oriented more to problem-solving, teachers' background, including beliefs about teaching and learning mathematics and teacher preparation program and past school experience, should be taken into account. Besides, teaching mathematics while teachers are being prepared would be the subject for further studies. We believe that equipping pre-service teachers with positive beliefs about mathematical problem solving would enable them to comply with the $\mathrm{CBC}$ requirements in their careers. It will help improve the quality of mathematics teaching, especially in implementing and developing problem-solving skills for both students and teachers.

\section{Acknowledgments}

We thank the African Centre of Excellence for Innovative Teaching and Learning Mathematics and Science (ACEITLMS) for funding this research. We also acknowledge participants teachers from Kayonza District, cited studies, and studies we picked to obtain the mathematical problem-solving beliefs scale.

\section{References}

Arikan, E. E. (2016). Prospective Teachers ' Beliefs a bout Problem Solving in Multiple Ways. Universal Journal of Educational Research, 4(7), 1727-1733. https:/ / doi.org/10.13189/ujer.2016.040727 
Barak, M. (2013). Impacts of learning inventive problem-solving principles: Students' transition from systematic searching to heuristic problem solving. Instructional Science, 41(4), 657-679.

Beswick, K. (2012). Teachers' beliefs about school mathematics and mathematicians' mathematics and their relationship to practice. Educational Studies in Mathematics, 79(1), 127-147.

Beswick, K. (2019). The role of knowledge and beliefs in helping learners to progress their mathematical understanding. Journal of Mathematics Teacher Education, 22(2), 125128. https://doi.org/10.1007/s10857-019-09432-5

Bloom, B. et al. (1972). Taxonomy of Educational Objektives. The Classification of Educational Goals. Handbook I: The Cognitive Domain. D. Mckay.

Bobis, J., Way, J., Anderson, J., \& Martin, A. J. (2015). Challenging teacher beliefs about student engagement in mathematics. https:// doi.org/10.1007/s10857-015-9300-4

Cheng, S., She, H., \& Huang, L. (2018). The Impact of Problem-Solving Instruction on Middle School Students' Physical Science Learning: Interplays of Knowledge, Reasoning, and Problem Solving. EURASIA Journal of Mathematics, Science and Technology Education, 14(3), 731-743.

Cresswell, J. W. (2014). Research Design: Qualitative, Quantitative and Mixed Methods Appoaches. In Sage Publications (4th editio). Sage Publications. https://doi.org/10.1063/1.1150549

Emenaker, C. (1996). A Problem-Solving Based Mathematics Course and Elementary Teachers' Beliefs. School Science and Mathematics, 96(2), 75-84.

Ernest, P. (1989). The impact of beliefs on the teaching of mathematics. In P. Ernest (Ed.), Mathematics teaching: The state of the art (pp. 249-253).

Fox, S. (1997). Situated learning theory versus traditional cognitive learning theory: Why management education should not ignore management learning. Systems Practice, 10(6), 727-747. https:// doi.org/10.1007/BF02557922

Hart, L. C. (2002). Preservice Teachers' Beliefs and Practice After Participating in an Integrated Content/Methods Course. School Science and Mathematics, 102(1), 4-14.

Hwang, J., \& Riccomini, P. J. (2016). Enhancing Mathematical Problem Solving for Secondary Students with or at Risk of Learning Disabilities: A Literature Review. Learning Disabilities Research and Practice. https://doi.org/10.1111/ldrp.12105

Kloosterman, P., \& Stage, F. K. (1992). Measuring Beliefs About Mathematical Problem Solving. School Scienca and Mathematics, 92(3), 109-115.

Marshman, M., \& Goos, M. (2018). The Beliefs about Mathematics, its Teaching and Learning of those Involved in Secondary Mathematics Pre-Service Teacher Education. Proceedings of the 41st Annual Conference of the Mathematics Education Research Group of Australasia, 519-526.

Memnun, D. S., Hart, L. C., \& Akkaya, R. (2012). A Research on the Mathematical Problem Solving Beliefs of Mathematics, Science and Elementary Pre-Service Teachers in Turkey in terms of Different Variables. International Journal of Humanities and Social Science, 2(24), 172-184.

Mukuka, A., Balimuttajjo, S., \& Mutarutinya, V. (2020). Exploring Students' Algebraic Reasoning on Quadratic Equations: Implications for School-Based Assessment. In K. K. Mashood, T. Sengupta, C. Ursekar, H. Raval, \& S. Dutta (Eds.), Proceedings of the epiSTEME8 International Conference to review research in Science, Technology and Mathematics Education (pp. 130-138). Homi Bhabha Centre for Science Education.

Ndihokubwayo, K., Ndayambaje, I., \& Uwamahoro, J. (2020). Analysis of Lesson Plans from Rwandan Physics Teachers. International Journal of Learning, Teaching and Educational Research, 19(12), 1-29. https://doi.org/10.26803/ijlter.19.12.1 
Nsengimana, T., Mugabo, L. R., \& Hiroaki, O. (2020). Reflection on science competencebased curriculum implementation in Sub-Saharan African countries. International Journal of Science Education, Part B, 0(0), 1-14.

Orodho, A., Nzabarirwa, W., Odundo, P., Waweru, P. N., \& Ndayambaje, I. (2016). Quantitative and Qualitative Research Methods. A Step by Step Guide to Scholarly Excellence. Kanezja Publishers \& Entreprises.

Pajares, M. F. (1992). Teachers' Beliefs and Educational Research: Cleaning Up a Messy Construct. Review of Educational Research, 62(3), 307-332.

Palraj, S., Dewitt, D., \& Alias, N. (2017). Teachers Beliefs in Problem Solving in Rural Malaysian Secondary Schools. Malaysian Online Journal of Educational Technology, $5(4), 45-57$.

Polly, D., Mcgee, J. R., Wang, C., Lambert, G., Pugalee, D. K., \& Johnson, S. (2013). The Association between Teachers 'Beliefs, Enacted Practices, and Student Learning in Mathematics. 22(2), 11-30.

Raymond, A. M. (1997). Inconsistency between a beginning elementary school teacher's mathematics beliefs and teaching practice. Journal for Research in Mathematics Education, 28(5), 550-576.

REB. (2019). Subsidiary Mathematics Senior 6 Teacher's Guide. Rwanda Education Board.

Ren, L., \& Smith, W. M. (2017). Teacher characteristics and contextual factors: links to early primary teachers' mathematical beliefs and attitudes. Journal of Mathematics Teacher Education, 21(4), 321-350.

Roesken, B., Pepin, B., \& Toerner, G. (2011). Beliefs and beyond: Affect and the teaching and learning of mathematics. ZDM - International Journal on Mathematics Education, 43(4), 451-455.

Rwanda Basic Education Board [REB]. (2015). Competency-based curriculum-summary of curriculum framework pre-primary to upper secondary.

Siswono, Kohar, \& Hartono. (2017). Secondary Teachers' Mathematics-related Beliefs and Knowledge about Mathematical Problem-solving. Journal of Physics: Conference Series, 1-7.

Siswono, Tatag Y.E., Kohar, A. W., Rosyidi, A. H., \& Hartono, S. (2017). Primary school teachers' beliefs and knowledge about mathematical problem-solving and their performance in a problem-solving task. World Transactions on Engineering and Technology Education, 15(2), 126-131.

Siswono, Tatag Yuli Eko, Hartono, S., Kohar, A. W., Karim, \& Kurniawan. (2019). Instrumentalist Teachers ' Beliefs in Practicing Mathematical Problem Solving. Universal Journal of Educational Research 7(12):, 7(12), 2851-2856.

Ukobizaba, F., Ndihokubwayo, K., Mukuka, A., \& Uwamahoro, J. (2019). Insights of teachers and students on mathematics teaching and learning in selected Rwandan secondary schools. African Journal of Educational Studies in Mathematics and Sciences, 15(2), 93-107.

Ukobizaba, F., Ndihokubwayo, K., \& Uworwabayeho, A. (2020). Teachers ' Behaviours Towards Vital Interactions that Attract Students ' Interest to Learn Mathematics and Career Development. African Journal of Educational Studies in Mathematics and Sciences, 16(1), 85-94.

Xenofontos, C., \& Andrews, P. (2012). Prospective teachers' beliefs about problem-solving: Cypriot and English cultural constructions. Research in Mathematics Education, 14(1), 69-85. https://doi.org/10.1080/14794802.2012.657439

Zakaria, E., \& Maat, siti M. (2012). Mathematics Teachers ' Beliefs and Teaching Practices. Journal of Mathematics and Statistics, 8(2), 187-190.

Zollman, A., \& Mason, E. (1992). The Standards' Beliefs Instrument (SBI): Teachers' Beliefs About the NCTM Standards. School Science and Mathematics, 92(7), 359-364. 